\title{
Penerapan Algoritma Genetika Untuk Optimasi Pembelian Sembako Sebagai Solusi Dari Knapsack Problem
}

\author{
Fachry Asy'ari \\ Program Studi Teknik Informatika \\ Jurusan Teknologi Informasi \\ Politeknik Negeri Jember \\ Jember, Indonesia \\ fcry1997@gmail.com \\ Al Faris Cahya Pratama \\ Program Studi Teknik Informatika \\ Jurusan Teknologi Informasi \\ Politeknik Negeri Jember \\ Jember, Indonesia
}

Trismayanti Dwi Puspitasari

Program Studi Teknik Informatika

Jurusan Teknologi Informasi

Politeknik Negeri Jember

Jember, Indonesia

trismayantidwipuspitasari@gmail.com

\author{
Avinda Renaldi Alamsyah \\ Program Studi Teknik Informatika \\ Jurusan Teknologi Informasi \\ Politeknik Negeri Jember \\ Jember, Indonesia
}

Dian Pusparini

Program Studi Teknik Informatika

Jurusan Teknologi Informasi

Politeknik Negeri Jember

Jember, Indonesia

\author{
Cahya Affrillah Prasetyo \\ Program Studi Teknik Informatika \\ Jurusan Teknologi Informasi \\ Politeknik Negeri Jember \\ Jember, Indonesia
}

Najmi Nurus Shofi

Program Studi Teknik Informatika

Jurusan Teknologi Informasi

Politeknik Negeri Jember

Jember, Indonesia

\begin{abstract}
Knapsack Problems are everyday problems related to optimization in elections, one example is the Purchase of Grocery. Groceries purchase is a process of selecting the optimization of goods according to the needs of the buyer so that the goods obtained can be maximized by taking into account the costs owned. For this optimization, this research uses Genetic Algorithms. Genetic Algorithm is considered optimal in cases related to the total price of goods, making it suitable for the selection of nine-basic necessities with different prices and brands. The algorithm in this research is carried out by determining the initial population containing randomly selected individuals, then by the process of selection and evolution, a new population is found that matches the desired results at the start, which is in accordance with the costs they have. In this study, the results of an increase in fitness from generation 1 to generation 2. This shows that the second generation produces individuals who are better than the first generation.
\end{abstract}

Keywords- Genetic Algorithm; Knapsack Problem; Optimization of goods

Abstrak - Knapsack Problem adalah permasalahan seharihari yang berhubungan dengan optimasi pada pemilihan, salah satu contohnya adalah Pembelian Sembako. Pembelian Sembako merupakan sebuah proses pemilihan optimasi barang sesuai dengan kebutuhan pembeli agar barang yang diperoleh dapat maksimal dengan memperhatikan biaya yang dimiliki. Untuk optimasi tersebut maka penelitian ini menggunakan Algoritma Genetika. Algoritma Genetika dinilai optimal dalam kasus yang berkaitan dengan total harga barang, sehingga cocok untuk pemilihan sembako yang berbeda harga dan merk. Algoritma di penelitian ini dilakukan dengan penentuan populasi awal yang berisi individu-individu yang dipilih secara acak ,yang kemudian dengan proses seleksi dan evolusi didapatkan populasi baru yang sesuai dengan hasil yang diinginkan di awal yaitu sesuai dengan biaya yang dimiliki. Dalam penelitian ini didapatkan hasil kenaikan pada fitness dari generasi 1 ke generasi 2 . Hal ini menunjukkan bahwa generasi kedua menghasilkan individu-individu yang lebih baik daripada generasi pertama.

Keywords- Algoritma Genetika; Knapsack Problem; Optimasi Barang

\section{PENDAHULUAN}

Knapsack Problem merupakan permasalahan yang sering muncul dalam kehidupan sehari-hari, sehingga persoalan ini sangat menarik untuk diteliti karena mudah untuk diimplementasikan pada kehidupan nyata. Knapsack problem sendiri adalah sebuah permasalahan dimana seseorang dihadapkan pada permasalahan optimasi pada pemilihan benda yang dapat dimasukkan ke dalam wadah yang memiliki keterbatasan ruang atau daya tampung, contohnya adalah pembelian sembako.

Secara tidak langsung, pembelian sembako merupakan sebuah contoh proses pemilihan optimasi barang dalam kehidupan sehari-hari. Permasalahan yang biasanya muncul adalah bagaimana pembeli dapat memaksimalkan pembelian dengan biaya yang terbatas dan terpenuhinya barang yang memiliki prioritas tinggi. Untuk optimalisasi proses tersebut, maka hal hal yang perlu diperhatikan adalah berat tiap barang, harga dan juga uang yang dimiliki oleh konsumen. Penerapan Algoritma Genetika untuk memberikan solusi pada Knapsack Problem sudah pernah dilakukan sebelumnya. Beberapa diantanya yaitu implementasi algoritma genetika pada optimasi pemilihan buah kemasan kotak yang menjelaskan tentang optimasi dari item item yang dapat dipilih untuk dimasukkan ke dalam Knapsack tanpa melewati kapasitas yang ada [3]. Penelitian lain menjelaskan perbandingan antara algoritma genetika dan algoritma greedy di dalam penyelesaian permasalahan Knapsack problem. Dari penelitian tersebut didapatkan sebuah kesimpulan bahwa baik algoritma genetika dan algoritma greedy samasama dapat menyelesaikan Knapsack problem. Akan tetapi algoritma genetika lebih optimal dalam kasus dengan jumlah 
harga barang. Sedangkan algoritma greedy unggul dalam kompleksitas waktu pencarian solusi [1]

Knapsack adalah tas atau karung. Karung digunakan untuk memuat sesuatu. Dan tentunya tidak semua objek dapat ditampung di dalam karung tersebut. Karung tersebut hanya dapat menyimpan beberapa objek dengan total ukurannya (weight) lebih kecil atau sama dengan ukuran kapasitas karung [2].

Algoritma genetika adalah algoritma pencarian yang didasarkan atas mekanisme dari seleksi alam yang lebih dikenal dengan proses evolusi. Dalam proses evolusi, individu secara terus menerus mengalami perubahan gen untuk menyesuaikan dengan lingkungan hidupnya. Hanya individu-individu yang kuat yang mampu bertahan. Proses seleksi alamiah ini melibatkan perubahan gen yang terjadi pada individu melalui proses perkembang-biakan. Algoritma genetika mampu menghasilkan solusilebih dari satu, hal ini disebabkan karena selama prosesnya, algoritma genetika menghasilkan solusi optimasi kombinatorial yang mirip solusi optimalnya. Peningkatan jumlah populasi akan memberikan ruang solusi yang semakin banyak, sehingga solusi optimal yang ditemukan juga semakin sempurna. oleh sebab itu dapat dikatakan bahwa semakin besar jumlah populasi maka akan memberikan nilai fitness yang semakin tinggi [4].

Secara umum, dalam algoritma genetika terdapat 5 (lima) proses, yaitu: pembentukan populasi awal, perhitungan nilai fitness, seleksi, regenerasi (crossover dan mutasi), penciptaan populasi baru hasil regenerasi. Proses rekombinasi atau yang lebih dikenal dengan nama proses crossover adalah menyilangkan dua kromosom sehingga membentuk kromosom baru yang harapannya lebih baik dari pada induknya. Tidak semua kromosom pada suatu populasi akan mengalami proses rekombinasi. Kemungkinan suatu kromosom mengalami proses rekombinasi didasarkan pada probabilitas crossover yang telah ditentukan terlebih dahulu. Probabilitas crossover menyatakan peluang suatu kromosom akan mengalami crossover. Ada beberapa teknik rekombinasi yang dapat digunakan untuk menyelesaikan Traveling Salesman Problem, antara lain adalah partially mapped crossover (PMX), order crossover dan cycle crossover [6].

Fokus utama pada penelitian ini adalah implementasi algoritma genetika untuk optimasi pemilihan sembako sebagai salah satu kasus dalam Knapsack problem. Dengan penelitian ini, diharapkan dapat dikembangkannya sebuah system yang memudahkan konsumen di dalam optimasi barang dari harga yang dimiliki.

\section{METODE PENELITIAN}

Cara kerja program secara garis besar adalah mencari total harga yang tidak melebihi batas uang maksimal. Pencariannya menggunakan algoritma genetika. Berikut adalah gambar blok diagram sistem.

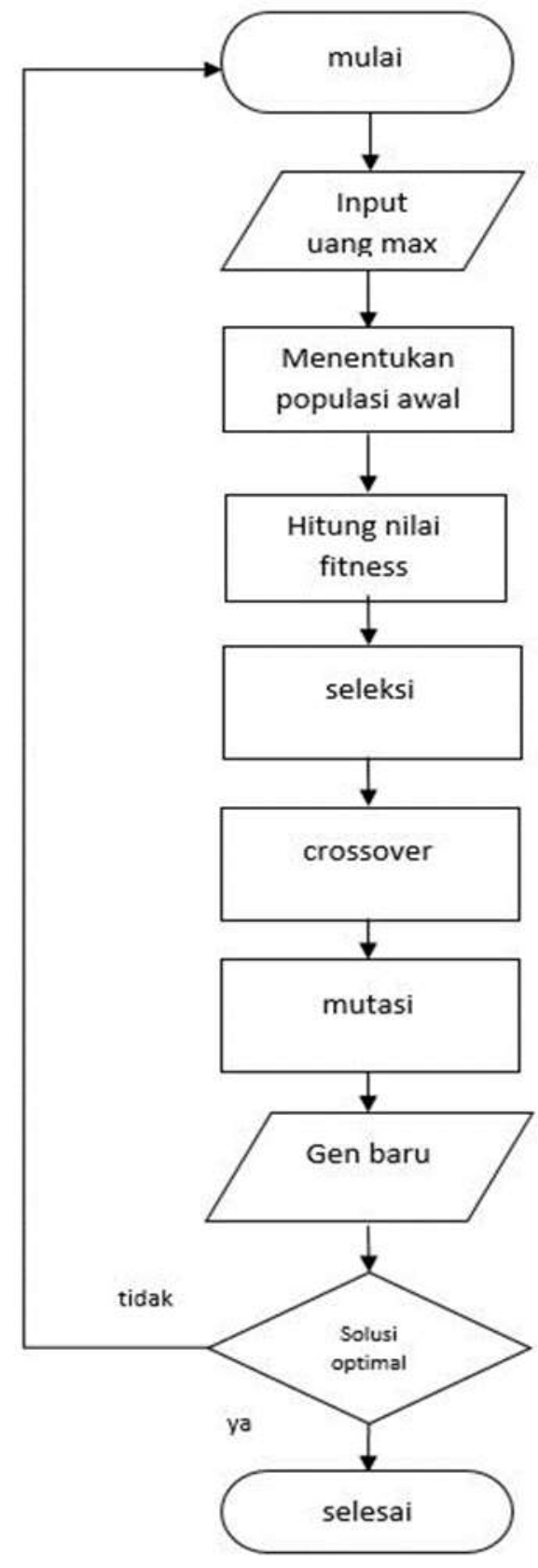

\section{Representasi Kromosom}

Gambar 1. Alur kerja sistem

Dalam kasus Knapsack problem, gen dari kromosom direpresentasikan dalam bentuk angka. Caranya dengan memilih nomor dari masing - masing jenis yang kemudian dijadikan gen untuk kromosom secara berurutan. Dengan demikian panjang dari kromosom nanti adalah 9 digit (sejumlah jenis barang).

Data barang yang nantinya akan dicari kombinasinya berdasarkan algoritma genetika adalah sebagai berikut :

TABEL I

DAFTAR TELUR AYAM

\begin{tabular}{|l|lr|l|l|}
\hline No & Merek & & Berat & Harga \\
\hline 1 & $\begin{array}{lr}\text { Sajira } \\
\text { Telur }\end{array}$ & $\begin{array}{r}\text { Farm } \\
\text { Ayam }\end{array}$ & $3 \mathrm{~kg}$ & 73.750 \\
$\begin{array}{l}\text { Negeri } \\
\text { butir] }\end{array}$ & {$[30$} & & \\
\hline 2 & Sajira & Telur & $3 \mathrm{~kg}$ & 91.000 \\
\hline
\end{tabular}




\begin{tabular}{|l|l|l|l|}
\hline & $\begin{array}{l}\text { Ayam Kampung } \\
\text { [30 butir] }\end{array}$ & & \\
\hline 3 & $\begin{array}{l}\text { Duta Buah } \\
\text { Pusat Telur } \\
\text { Ayam Negeri } \\
\text { 17 butir] }\end{array}$ & & 26.500 \\
\hline 4 & $\begin{array}{l}\text { Duta Buah } \\
\text { Telur Ayam } \\
\text { Kampung } \\
\text { Merah [10 butir] }\end{array}$ & & \\
\hline 5 & $\begin{array}{l}\text { Sajira Farm } \\
\text { Telur Ayam } \\
\text { Negeri [10 } \\
\text { butir] }\end{array}$ & \\
\hline
\end{tabular}

TABEL II

DAFTAR SUSU KENTAL MANIS

\begin{tabular}{|l|l|l|l|}
\hline No & Merek & Berat & Harga \\
\hline 1 & $\begin{array}{l}\text { Fisian Flag Susu } \\
\text { Kental Manis } \\
\text { Kaleng }\end{array}$ & $0,370 \mathrm{~kg}$ & 9.900 \\
\hline 2 & $\begin{array}{l}\text { Frisian Flag } \\
\text { Susu } \quad \text { kental } \\
\text { Manis - Gold } \\
\text { Kaleng }\end{array}$ & & \\
\hline 3 & $\begin{array}{l}\text { Frisian Flag } \\
\text { Susu Kental } \\
\text { Manis Pouch }\end{array}$ & $0,560 \mathrm{~kg}$ & 14.500 \\
\hline 4 & $\begin{array}{l}\text { Cap Enaak Susu } \\
\text { Kental Manis } \\
\text { Kaleng }\end{array}$ & $0,370 \mathrm{~kg}$ & 9.200 \\
\hline 5 & $\begin{array}{l}\text { Indomilk Plain } \\
\text { Susu Kental } \\
\text { Manis Kaleng } \\
{[3 \text { pcs] }}\end{array}$ & & \\
\hline
\end{tabular}

TABEL III

DAFTAR JAGUNG

\begin{tabular}{|l|l|l|l|}
\hline No & Merek Herat & Harga \\
\hline 1 & $\begin{array}{l}\text { Qooali Jagung } \\
\text { Manis }\end{array}$ & $0,650 \mathrm{~kg}$ & 9.500 \\
\hline 2 & $\begin{array}{l}\text { Qooali Jagung } \\
\text { Manis Besar }\end{array}$ & $1,500 \mathrm{~kg}$ & 20.000 \\
\hline 3 & $\begin{array}{l}\text { FreshBox } \\
\text { Jagung Manis } \\
\text { Kupas }\end{array}$ & $1 \mathrm{~kg}$ & 14.500 \\
\hline 4 & $\begin{array}{l}\text { Alif } \\
\text { Cooperation } \\
\text { Jagung Manis }\end{array}$ & $0,500 \mathrm{~kg}$ & 7.000 \\
\hline 5 & $\begin{array}{l}\text { Alif } \\
\text { Cooperation } \\
\text { Jagung Acar }\end{array}$ & $0,250 \mathrm{~kg}$ & 8.000 \\
\hline
\end{tabular}

TABEL IV

DAFTAR MIE

\begin{tabular}{|l|l|l|l|}
\hline No & Merek & Berat & Harga \\
\hline 1 & $\begin{array}{l}\text { Indomie Mie } \\
\text { Goreng Special } \\
{[40 \mathrm{pcs}]}\end{array}$ & $3,4 \mathrm{~kg}$ & 99.500 \\
\hline
\end{tabular}

\begin{tabular}{|l|l|l|l|}
\hline 2 & $\begin{array}{l}\text { Indomie Mie } \\
\text { Kari Ayam [40 } \\
\text { pcs] }\end{array}$ & $2,88 \mathrm{~kg}$ & 93.000 \\
\hline 3 & $\begin{array}{l}\text { Indomie Mie } \\
\text { Goreng Special }\end{array}$ & $0,085 \mathrm{~kg}$ & 2.850 \\
\hline 4 & $\begin{array}{l}\text { Indomie Mie } \\
\text { Goreng Special } \\
{[10 \text { pcs] }}\end{array}$ & $0,85 \mathrm{~kg}$ & 25.900 \\
\hline 5 & $\begin{array}{l}\text { Indomie Rasa } \\
\text { Soto [5 pcs] }\end{array}$ & $0,375 \mathrm{~kg}$ & 11.500 \\
\hline
\end{tabular}

TABEL V

DAFTAR BERAS

\begin{tabular}{|l|l|l|l|}
\hline No & Merek & Berat & Harga \\
\hline 1 & Topi Kaki & $5 \mathrm{~kg}$ & 64.000 \\
\hline 2 & Fortune & $5 \mathrm{~kg}$ & 60.000 \\
\hline 3 & Rojo Lele & $5 \mathrm{~kg}$ & 60.500 \\
\hline 4 & Sania & $2,5 \mathrm{~kg}$ & 35.000 \\
\hline 5 & $\begin{array}{l}\text { Beras Coklat } \\
\text { Keep Me First }\end{array}$ & $2,5 \mathrm{~kg}$ & 85.000 \\
\hline 6 & Sumo & $10 \mathrm{~kg}$ & 128.000 \\
\hline
\end{tabular}

TABEL VI

DAFTAR GULA

\begin{tabular}{|l|l|l|l|}
\hline No & Merek & Berat & Harga \\
\hline 1 & $\begin{array}{l}\text { Gulaku } \\
\text { Premium }\end{array}$ & $1 \mathrm{~kg}$ & 13.000 \\
\hline 2 & Fs Gula Pasir & $1 \mathrm{~kg}$ & 12.600 \\
\hline 3 & Rose Brand & $1 \mathrm{~kg}$ & 12.000 \\
\hline 4 & $\begin{array}{l}\text { Matahari Merah } \\
\text { Premium }\end{array}$ & $1 \mathrm{~kg}$ & 11.500 \\
\hline 5 & Gulaku Tebu & $0,5 \mathrm{~kg}$ & 7.000 \\
\hline 6 & Tropicana Slim & $0,25 \mathrm{~kg}$ & 74.000 \\
\hline 7 & Manise & $0,5 \mathrm{~kg}$ & 6.900 \\
\hline
\end{tabular}

TABEL VII

DAFTAR MINYAK GORENG

\begin{tabular}{|l|l|l|l|}
\hline No & Merek & Berat & Harga \\
\hline 1 & Bimoli [1 pcs] & 2 L & 24.500 \\
\hline 2 & $\begin{array}{l}\text { Rose Brand [1 } \\
\text { pcs] }\end{array}$ & $2 \mathrm{~L}$ & 20.900 \\
\hline 3 & Tropica [1 pcs] & $2 \mathrm{~L}$ & 26.000 \\
\hline 4 & Tropica [6 pcs] & $2 \mathrm{~L}$ & 137.000 \\
\hline 5 & Fortune [1 pcs] & 2 L & 25.000 \\
\hline 6 & Sania [1 pcs] & $2 \mathrm{~L}$ & 21.900 \\
\hline 7 & Filma [1 pcs] & 2 L & 30.000 \\
\hline 8 & Filma [6 pcs] & 2 L & 126.000 \\
\hline
\end{tabular}

TABEL VIII

DAFTAR GARAM

\begin{tabular}{|l|l|l|l|}
\hline No & Merek & Berat & Harga \\
\hline 1 & Garena [1 pcs] & $1 \mathrm{~kg}$ & 15.000 \\
\hline 2 & Dolpin [1 pcs] & $1 \mathrm{~kg}$ & 12.000 \\
\hline 3 & $\begin{array}{l}\text { Real Salt } \\
\text { Kosher } \\
{[1 \mathrm{pcs}]}\end{array}$ & $0,454 \mathrm{~kg}$ & 160.000 \\
\hline 4 & $\begin{array}{l}\text { Redmond Real } \\
\text { Salt [1 pcs] }\end{array}$ & $0,454 \mathrm{~kg}$ & 190.000 \\
\hline 5 & Real Salt Fine & $0,454 \mathrm{~kg}$ & 154.000 \\
\hline
\end{tabular}




\section{$[1 \mathrm{pcs}]$}

TABEL IX

DAFTAR DAGING AYAM

\begin{tabular}{|l|l|l|l|}
\hline No & Bagian & Berat & Harga \\
\hline 1 & Sayap & $1 \mathrm{~kg}$ & 32.000 \\
\hline 2 & Paha & $1 \mathrm{~kg}$ & 38.000 \\
\hline 3 & Ayam Karkas & $0,8 \mathrm{~kg}$ & 42.000 \\
\hline 4 & Kulit & $1 \mathrm{~kg}$ & 29.000 \\
\hline 5 & Ceker & $1 \mathrm{~kg}$ & 27.000 \\
\hline 6 & Dada & $1 \mathrm{~kg}$ & 42.500 \\
\hline
\end{tabular}

\section{Fungsi Fitness}

Setiap kromosom dievaluasi berdasarkan fungsi tertentu sebagai nilai fitness. Dalam Knapsack problem, untuk mencari nilai fitness yakni dengan menemukan total harga dari semua barang terpilih kurang dari atau sama dengan batas harga yang telah ditentukan. Sehingga fungsi nilai fitness adalah

$$
f= \begin{cases}\sum_{k=1}^{n} h_{k}, & j i k a \sum_{k=1}^{n} h_{k} \leq h M a x \\ \sum_{k=1}^{n} h_{k}-h M a x, & j i k a \sum_{k=1}^{n} h_{k}>h M a x\end{cases}
$$

keterangan :

$h_{k}=$ harga barang ke $k$

$h$ Max $=$ uang maksimal

\section{Seleksi}

Untuk melakukan proses seleksi pada masalah Knapsack problem, digunakan metode seleksi berdasarkan roulette wheel. Langkah - langkah penyelesaiannya adalah

a. Hitung probabilitas fitness dari masing - masing kromosom

$$
p_{i}=\frac{f_{i}}{f t}
$$

keterangan :

$p_{i}=$ probabilitas fitness ke $i$

$f_{i}=$ fitness ke $i$

$f t=$ total fitness

b. Hitung fitness kumulatif untuk masing - masing kromosom dari probabilitas

$$
f k=p_{i}+f k
$$

keterangan :

$p_{i}=$ probabilitas fitness ke $i$

$f k=$ fitness kumulatif

c. Melakukan proses pemutaran roulette wheel sebanyak total populasi. Angka yang didapatkan kemudian dijadikan acuan untuk memilih kromosom baru.

\section{Crossover}

Crossover dilakukan dua kromosom untuk menghasilkan kromosom anak, crossover dalam kasus ini menggunakan one point crossover. one point crossover adalah metode crossover dalam genetika algoritma dengan cara membagi dua ruas bagian kiri dan kanan, kemudian dapat memilih bagian kanan atau kiri yang akan dicrossover.

\section{Mutasi}

Mutasi adalah salah satu proses untuk merubah secara acak nilai dari suatu gen pada posisi yang dipilih. Perubahan nilai pada permasalahan ini yaitu dengan mengacak nilai sesuai batas angka dari tipe masing - masing jenis. Untuk menentukan gen yang akan dimutasi adalah sebagai berikut :

a. Menghitung jumlah gen dari kromosom dikali populasi.

\section{tGen $=j$ Gen $\times$ po}

\section{keterangan :}

$t$ Gen $=$ total gen seluruh populasi

$j G e n=$ total gen dalam 1 kromosom

po $=$ total kromosom dalam populasi

b. Menentukan persentase peluang mutasi yang kemudian dikali dengan total gen yang telah dihitung sebelumnya. Hasilnya adalah jumlah gen yang akan dimutasi.

$m G e n=p m \times t G e n$

keterangan :

$m G e n=$ jumlah gen yang dimutasi

pm $=$ peluang mutasi

\section{HASIL DAN PEMBAHASAN}

Hasil penerapan dari metode yang dijelaskan sebelumnya pada sebuah permasalahan adalah sebagai berikut :

\section{Menentukan Populasi Awal}

Untuk batas uang yang ditentukan dalam permasalahan ini adalah Rp. 350,000,-. Kemudian untuk populasi awal yang dibangkitkan sesuai dengan representasi kromosom adalah

TABEL $X$

STRUKTUR KROMOSOM POPULASI AWAL

\begin{tabular}{|l|l|l|l|l|l|l|l|l|l|}
\hline & $\begin{array}{l}\text { Be } \\
\text { ras }\end{array}$ & $\begin{array}{l}\text { G } \\
\mathbf{u} \\
\mathbf{l} \\
\mathbf{a}\end{array}$ & $\begin{array}{l}\text { Min } \\
\text { yak } \\
\text { Gor } \\
\text { eng }\end{array}$ & $\begin{array}{l}\text { Dag } \\
\text { ing } \\
\text { Aya } \\
\text { m }\end{array}$ & $\begin{array}{l}\text { Telur } \\
\text { Ayam }\end{array}$ & $\begin{array}{l}\text { Susu } \\
\text { Kental } \\
\text { Manis }\end{array}$ & $\begin{array}{l}\text { Jag } \\
\text { ung }\end{array}$ & Mie & $\begin{array}{l}\text { Gara } \\
\text { m }\end{array}$ \\
\hline K1 & 5 & 5 & 3 & 5 & 5 & 3 & 4 & 5 & 2 \\
\hline K2 & 3 & 1 & 1 & 6 & 1 & 3 & 2 & 1 & 2 \\
\hline K3 & 6 & 1 & 3 & 1 & 2 & 2 & 1 & 2 & 1 \\
\hline K4 & 1 & 3 & 2 & 1 & 1 & 1 & 3 & 3 & 3 \\
\hline K5 & 4 & 7 & 1 & 2 & 3 & 1 & 1 & 4 & 4 \\
\hline
\end{tabular}

\section{Fungsi Fitness}

Nilai hMax didapat dari batas uang yang ditentukan sebelumnya sebesar Rp 350,000,-. Sehingga didapatkan nilai fitness untuk masing - masing kromosom sesuai dengan rumus yang telah ditentukan sebagai berikut :

TABEL XI

NILAI FITNESS TIAP KROMOSOM POPULASI AWAL

\begin{tabular}{|l|l|l|l|l|}
\hline No & Kromosom & Total Berat & Total Harga & Fitness \\
\hline 1 & $\mathrm{~K} 1$ & $\mathrm{~kg}$ & 237.000 & 237.000 \\
\hline 2 & $\mathrm{~K} 2$ & $\mathrm{~kg}$ & 360.250 & 10.250 \\
\hline 3 & $\mathrm{~K} 3$ & $\mathrm{~kg}$ & 421.600 & 71.600 \\
\hline 4 & $\mathrm{~K} 4$ & $\mathrm{~kg}$ & 389.900 & 39.900 \\
\hline 5 & $\mathrm{~K} 5$ & $\mathrm{~kg}$ & 366.200 & 16.200 \\
\hline
\end{tabular}

\section{Seleksi}

Nilai hMax didapat dari batas uang yang ditentukan sebelumnya sebesar Rp 350,000,-. Sehingga didapatkan 
nilai fitness untuk masing - masing kromosom sesuai dengan rumus yang telah ditentukan sebagai berikut :

TABEL XII

FITNESS KUMULATIF TIAP KROMOSOM POPULASI AWAL

\begin{tabular}{|l|l|l|l|l|l|}
\hline $\begin{array}{l}\mathbf{N} \\
\mathbf{o}\end{array}$ & $\begin{array}{l}\text { Kro } \\
\text { moso } \\
\text { m }\end{array}$ & $\begin{array}{l}\text { Total } \\
\text { Harga }\end{array}$ & Fitness & $\begin{array}{l}\text { Probabilitas } \\
\text { Fitness }\end{array}$ & $\begin{array}{l}\text { Fitness } \\
\text { Kumulatif }\end{array}$ \\
\hline 1 & K1 & 237.000 & 237.000 & 0,632 & 0,632 \\
\hline 2 & K2 & 360.250 & 10.250 & 0,027 & 0,659 \\
\hline 3 & K3 & 421.600 & 71.600 & 0,191 & 0,850 \\
\hline 4 & K4 & 389.900 & 39.900 & 0,106 & 0,956 \\
\hline 5 & K5 & 366.200 & 16.200 & 0,043 & 1 \\
\hline
\end{tabular}

Lalu dilakukan proses roulette wheel sebanyak 5 kali, dan dihasilkan bilangan sebagai berikut : TABEL XIII

HASIL DARI ROULETTE WHEEL UNTUK SELEKSI POPULASI AWAL

\begin{tabular}{|l|l|}
\hline No & Bilangan Acak \\
\hline 1 & 0,235 \\
\hline 2 & 0,317 \\
\hline 3 & 0,789 \\
\hline 4 & 0,697 \\
\hline 5 & 0,812 \\
\hline
\end{tabular}

Sehingga didapatkan kromosom baru dari proses seleksi kromosom awal yaitu :

TABEL XIV

HASIL KROMOSOM TERPILIH DARI ROULETTE WHEEL

\begin{tabular}{|l|l|l|l|l|}
\hline No & $\begin{array}{l}\text { Kromoso } \\
\mathbf{m}\end{array}$ & Fitness & $\begin{array}{l}\text { Probabilitas } \\
\text { Fitness }\end{array}$ & Asal \\
\hline 1 & K1 & 237.000 & 0,632 & K1 \\
\hline 2 & K2 & 237.000 & 0,632 & K1 \\
\hline 3 & K3 & 71.600 & 0,191 & K3 \\
\hline 4 & K4 & 71.600 & 0,191 & K3 \\
\hline 5 & K5 & 71.600 & 0,191 & K3 \\
\hline
\end{tabular}

\section{Crossover}

Untuk permasalahan ini, peluang crossover yang diharapkan adalah $40 \%$ dari total kromosom. Sehingga kromosom yang mengalami crossover adalah $40 \% * 5=2$ kromosom.

TABEL XV

HASIL DARI ROULETTE WHEEL UNTUK CROSSOVER

\begin{tabular}{|l|l|}
\hline No & Bilangan Acak \\
\hline 1 & 0,671 \\
\hline 2 & 0,172 \\
\hline 3 & 0,222 \\
\hline 4 & 0,593 \\
\hline 5 & 0,315 \\
\hline
\end{tabular}

Pilih bilangan - bilangan acak yang kurang dari peluang crossover, maka kromosom yang sesuai dengan urutan bilangan terpilih tadi yang akan di-crossover. Sehingga bilangan yang akan di-crossover adalah TABEL XVI

KROMOSOM YANG AKAN DI-CROSSOVER

\begin{tabular}{|l|l|l|l|l|}
\hline No & Kromosom & Fitness & $\begin{array}{l}\text { Probabilitas } \\
\text { Fitness }\end{array}$ & Asal \\
\hline 2 & K2 & 237.000 & 0,632 & K1 \\
\hline 3 & K3 & 71.600 & 0,191 & K3 \\
\hline
\end{tabular}

Karena kita menggunakan one-point crossover, maka crossover untuk kromosom 2 dan 3 adalah :
TABEL XVII

KROMOSOM YANG AKAN DI-CROSSOVER

\begin{tabular}{|l|l|l|l|l|l|l|l|l|l|}
\hline & $\begin{array}{l}\text { Be } \\
\text { ras }\end{array}$ & $\begin{array}{l}\text { G } \\
\mathbf{u} \\
\mathbf{1}\end{array}$ & $\begin{array}{l}\text { Min } \\
\text { yak } \\
\text { Gor } \\
\text { eng }\end{array}$ & $\begin{array}{l}\text { Dag } \\
\text { ing } \\
\text { Aya } \\
\mathbf{m}\end{array}$ & $\begin{array}{l}\text { Telur } \\
\text { Ayam }\end{array}$ & $\begin{array}{l}\text { Susu } \\
\text { Kental } \\
\text { Manis }\end{array}$ & $\begin{array}{l}\text { Jag } \\
\text { ung }\end{array}$ & Mie & $\begin{array}{l}\text { Gara } \\
\mathbf{m}\end{array}$ \\
\hline K2 & 3 & 1 & 1 & 6 & 1 & 3 & 2 & 1 & 2 \\
\hline K3 & 6 & 1 & 3 & 1 & 2 & 2 & 1 & 2 & 1 \\
\hline
\end{tabular}

Maka dihasilkan anak dari hasil crossover di atas sebagai berikut :

TABEL XVIII

HASIL DARI PROSES CROSSOVER

\begin{tabular}{|l|l|l|l|l|l|l|l|l|l|}
\hline & $\begin{array}{l}\text { Be } \\
\text { ras }\end{array}$ & $\begin{array}{l}\text { G } \\
\mathbf{u} \\
\mathbf{l} \\
\text { a }\end{array}$ & $\begin{array}{l}\text { Min } \\
\text { yak } \\
\text { Gor } \\
\text { eng }\end{array}$ & $\begin{array}{l}\text { Dag } \\
\text { ing } \\
\text { Aya } \\
\text { m }\end{array}$ & $\begin{array}{l}\text { Telur } \\
\text { Ayam }\end{array}$ & $\begin{array}{l}\text { Susu } \\
\text { Kental } \\
\text { Manis }\end{array}$ & $\begin{array}{l}\text { Jag } \\
\text { ung }\end{array}$ & Mie & $\begin{array}{l}\text { Gara } \\
\text { m }\end{array}$ \\
\hline K2 & 3 & 1 & 1 & 1 & 2 & 2 & 1 & 2 & 1 \\
\hline K3 & 6 & 1 & 3 & 6 & 1 & 3 & 2 & 1 & 2 \\
\hline
\end{tabular}

\section{Mutasi}

Sehingga untuk melakukan mutasi pada permasalahan diatas adalah $9 * 5=45$, lalu $20 \% * 45=9$. Didapatkan nilai sebagai berikut :

TABEL XIX

BILANGAN ACAK KROMOSOM 1

\begin{tabular}{|l|l|l|l|}
\hline No & Bilangan Acak & No & Bilangan Acak \\
\hline 1 & 0,3 & 6 & 0,4 \\
\hline 2 & 0,41 & 7 & 0,19 \\
\hline 3 & 0,55 & 8 & 0,56 \\
\hline 4 & 0,001 & 9 & 0,72 \\
\hline 5 & 0,3 & & \\
\hline
\end{tabular}

TABEL XX

BILANGAN ACAK KROMOSOM 2

\begin{tabular}{|l|l|l|l|}
\hline No & Bilangan Acak & No & Bilangan Acak \\
\hline 1 & 0,49 & 6 & 0,13 \\
\hline 2 & 0,56 & 7 & 0,24 \\
\hline 3 & 0,61 & 8 & 0,16 \\
\hline 4 & 0,72 & 9 & 0,14 \\
\hline 5 & 0,29 & & \\
\hline
\end{tabular}

TABEL XXI

BILANGAN ACAK KROMOSOM 3

\begin{tabular}{|l|l|l|l|}
\hline No & Bilangan Acak & No & Bilangan Acak \\
\hline 1 & 0,65 & 6 & 0,17 \\
\hline 2 & 0,59 & 7 & 0,51 \\
\hline 3 & 0,28 & 8 & 0,27 \\
\hline 4 & 0,78 & 9 & 0,26 \\
\hline 5 & 0,21 & & \\
\hline
\end{tabular}

TABEL XXII

BILANGAN ACAK KROMOSOM

\begin{tabular}{|l|l|l|l|}
\hline No & Bilangan Acak & No & Bilangan Acak \\
\hline 1 & 0,29 & 6 & 0,73 \\
\hline 2 & 0,27 & 7 & 0,28 \\
\hline 3 & 0,02 & 8 & 0,31 \\
\hline 4 & 0,81 & 9 & 0,62 \\
\hline 5 & 0,15 & & \\
\hline
\end{tabular}

TABEL XXIII

BILANGAN ACAK KROMOSOM 5

\begin{tabular}{|l|l|l|l|}
\hline No & Bilangan Acak & No & Bilangan Acak \\
\hline 1 & 0,34 & 6 & 0,35 \\
\hline 2 & 0,43 & 7 & 0,31 \\
\hline 3 & 0,41 & 8 & 0,67 \\
\hline 4 & 0,12 & 9 & 0,65 \\
\hline
\end{tabular}


Sehingga hasil dari roulette wheel untuk masing masing kromosom terpilih gen sebagai berikut :

TABEL XXIV

GEN YANG TERPILIH

\begin{tabular}{|l|l|l|l|}
\hline Kromosom & Gen ke & Kromosom & Gen ke \\
\hline 1 & 4 & 3 & 6 \\
\hline 1 & 7 & 4 & 5 \\
\hline 2 & 6 & 4 & 3 \\
\hline 2 & 8 & 5 & 4 \\
\hline 2 & 9 & & \\
\hline
\end{tabular}

Dari gen yang terpilih pada proses sebelumnya kemudian melakukan acak bilangan sesuai dengan batas masing - masing gen sehingga dapat dihasilkan populasi baru dengan kromosom sebagai berikut : TABEL XXV

HASIL MUTASI BERUPA POPULASI BARU

\begin{tabular}{|l|l|l|l|l|l|l|l|l|l|}
\hline & $\begin{array}{l}\text { Be } \\
\text { ras }\end{array}$ & $\begin{array}{l}\text { G } \\
\mathbf{u} \\
\mathbf{l} \\
\mathbf{a}\end{array}$ & $\begin{array}{l}\text { Min } \\
\text { yak } \\
\text { Gor } \\
\text { eng }\end{array}$ & $\begin{array}{l}\text { Dag } \\
\text { ing } \\
\text { Aya } \\
\mathbf{m}\end{array}$ & $\begin{array}{l}\text { Telur } \\
\text { Ayam }\end{array}$ & $\begin{array}{l}\text { Susu } \\
\text { Kental } \\
\text { Manis }\end{array}$ & $\begin{array}{l}\text { Jag } \\
\text { ung }\end{array}$ & Mie & $\begin{array}{l}\text { Gara } \\
\text { m }\end{array}$ \\
\hline K1 & 5 & 5 & 3 & 2 & 5 & 3 & 5 & 5 & 2 \\
\hline K2 & 3 & 1 & 1 & 1 & 2 & 3 & 1 & 2 & 2 \\
\hline K3 & 6 & 1 & 3 & 6 & 1 & 2 & 2 & 1 & 2 \\
\hline K4 & 6 & 1 & 2 & 1 & 3 & 2 & 1 & 3 & 1 \\
\hline K5 & 6 & 1 & 3 & 3 & 2 & 2 & 1 & 2 & 1 \\
\hline
\end{tabular}

\section{Mencari Solusi Optimal}

Untuk mencari solusi optimal dari populasi baru yaitu dengan cara mencari kembali nilai fitness dari masing masing kromosom pada populasi baru. Sehingga diketahui sebagai berikut :

TABEL XXVI

NILAI FITNESS DARI SETIAP KROMOSOM POPULASI BARU

\begin{tabular}{|l|l|l|l|l|}
\hline No & Kromosom & Total Berat & Total Harga & Fitness \\
\hline 1 & $\mathrm{~K} 1$ & $\mathrm{~kg}$ & 249.000 & 249.000 \\
\hline 2 & $\mathrm{~K} 2$ & $\mathrm{~kg}$ & 350.000 & 350.000 \\
\hline 3 & $\mathrm{~K} 3$ & $\mathrm{~kg}$ & 428.850 & 78.850 \\
\hline 4 & $\mathrm{~K} 4$ & $\mathrm{~kg}$ & 261.850 & 261.850 \\
\hline 5 & $\mathrm{~K} 5$ & $\mathrm{~kg}$ & 831.600 & 81.600 \\
\hline
\end{tabular}

TABEL XXVII

DAFTAR FITNESS SETIAP GENERASI

\begin{tabular}{|l|l|l|l|}
\hline $\begin{array}{l}\text { Generasi } \\
\text { ke }\end{array}$ & $\begin{array}{l}\text { Fitness } \\
\text { Terbaik }\end{array}$ & $\begin{array}{l}\text { Fitness } \\
\text { Terburuk }\end{array}$ & $\begin{array}{l}\text { Fitness } \\
\text { Rata - rata }\end{array}$ \\
\hline 1 & 237.000 & 10.250 & 123.625 \\
\hline 2 & 350.000 & 78.850 & 214.425 \\
\hline
\end{tabular}

Dari data fitness yang telah didapat, kemudian dijari nilai fitness yang sama dengan hMax. Sehingga didapatkan kromosom $K 2$ menjadi kombinasi yang sesuai dengan batas uang yang telah ditentukan, dengan detail barang yang dibeli adalah :

1. Beras $=$ Rojo lele

2. Gula $=$ Gulaku Premium

3. Minyak Goreng = Bimoli $[1$ pcs $]$

4. Daging Ayam = Sayap

5. Telur Ayam $=$ Sajira Telur Ayam Kampung $[30$ butir]

6. Susu Kental Manis = Frisian Flag Susu Kental Manis Pouch

7. Jagung $=$ Qooali Jagung Manis Besar

8. $\mathrm{Mie}=$ Indomie Kari Ayam [40 pcs]

\section{KESIMPULAN}

Penentuan statistik tiap generasi didapatkan dari nilai maximum (fitness terbaik) tiap generasi dan nilai minimum (fitness terburuk) tiap generasi. Selain dapat digunakan untuk optimasi pembelian sembako, Algoritma genetika memberikan kemudahan dalam menentukan kombinasi barang terutama pada studi kasus Knapsack problem yaitu dengan menggunakan parameter harga dari data barang. Pada penerapan algoritma genetika terdapat beberapa komponen penting yang berperan dalam studi kasus ini meliputi kromosom, seleksi, crossover, dan mutasi. Dimana dari beberapa komponen tersebut dapat melakukan proses perhitungan perolehan hasil kromosom terbaik. Dari studi kasus yang diangkat dapat ditarik kesimpulan bahwa terjadi kenaikan pada nilai fitness dari generasi 1 yaitu dengan nominal 273.000 ke generasi 2 dengan nilai fitness sebesar 350.000. Selain itu, nilai fitness rata-rata juga mengalami kenaikan dari generasi 1 ke 2 yaitu dari nominal 123.625 naik ke 214.425 .

\section{UCAPAN TERIMA KASIH}

Terimakasih kepada Politeknik Negeri Jember dan Dosen pengampu Mata Kuliah Sistem Cerdas.

\section{REFERENSI}

[1] N. Aima, Penerapan Algoritma Genetika dan Perbandingannya dengan Algoritma Greedy dalam Penyelesaian Knapsack Problem. Skripsi. Universitas Islam Negeri Alauddin Makassar, 2017.

[2] D. Rachmawati \& A.Candra, Implementasi Algoritma Greedy untuk Menyelesaikan Masalah Knapsack Problem. 2013. Jurnal SAINTIKOM Vol. 12, No. 3.

[3] Setemen, Komang. Implementasi Algoritma Genetika Pada Knapsack Problem Untuk Optimasi Pemilihan Buah Kemasan Kotak. 2010. Seminar Nasional Aplikasi Teknologi Informasi 2010 (SNATI 2010) ISSN: 1907-5022, Yogyakarta.

[4] Fitri, Mega Orina. 2017. Optimasi Pengangkutan Peti Kemas Dalam Penyelesaian Knapsack Berdasarkan Perbandingan Algoritma Genetika Dan Algoritma Greedy. Jurnal INSTEK (Informatika Sains dan Teknologi), vol 2 no 2

[5] K.Diah, M.Fadhli \& C.Sutanto, "Penyelesaian Knapsack Problem Menggunakan Algoritma Genetika. 2010. Seminar Nasional Informatika (SEMNASIF), vol 1 no 4.

[6] S.Lukas, T.Anwar \& W.Yuliani . Penerapan Algoritma Genetika Untuk Traveling Salesman Problem Dengan Menggunakan Metode Order Crossover Dan Insertion Mutation. 2005. Seminar Nasional Aplikasi Teknologi Informasi (SNATI).

[7] L.Tambunan, Implementasi Algoritma Genetika dalam Pembuatan Jadwal Kuliah, 2017. Jaringan Sistem Informasi Robotik (JSR), vol 1 , no 1 .

[8] IW.Supriana, Optimalisasi Penyelesaian Knapsack Problem Dengan Algoritma Genetika, 2016. Lontar Komputer (Jurnal Ilmiah Teknologi Informasi), vol 7 no 3.

[9] CWM Vermila, Analisis Karakteristik Konsumen

Yang Berbelanja Sembilan Bahan Pokok(Sembako) Di Pasar Tradisional Dan Pasar Moderen Di Kecamatan Marpoyan Damai Kota Pekanbaru. 2016. Jurnal Agribisnis, vol 18 no 2.

[10] (2019) The Pakarayam website [Online]. Tersedia:http//pakarayam.id/ 